\title{
Transport of Preimplantation Embryos in the Genitalia of Buffalo Heifers Superovulated with pFSH and Variable Doses of LH
}

\author{
A.M. Osman and S.H. Shehata \\ Dept.Theriogenology, Fac.Vet. Medicine, Assiut Univ., Assiut,Egypt.
}

\section{SUMMARY}

Twelve buffalo heifers of similar age (21-25 month) and body weight $(325-385 \mathrm{~kg})$ were superovulated during mid luteal phase using pFSH (total 65 NIH unit Super-Ov divided into 6 equal dose, $1.4 \mathrm{ml}$ each, for 3 consecutive days) and lutalyse $(25 \mathrm{mg}$ injected with the $5^{\text {th }}$ injection). To improve the ovarian response to the variable doses of $\mathrm{LH}(0,2,4,5,7$ and 10 thousands USP Unit, Steris, Lab. Inc Phoenix, Arizona) were injected at the morning of the $4^{\text {th }}$ day of the treatment in 6 trials $(n=2)$. Fertile bulls were allowed to mount heifers frequently after 24 hour (h) from onset of estrus. Heifers were classified into 3 equal groups ( 2 trials/each) which slaughtered at various time intervals from the onset of estrus: 72-89, 100-106 and 118-120 (h). After slaughter, the intact genitalia were dissected free and transported to the lab in a thermos container at $4 \mathrm{C}^{\circ}$. The number of newly formed corpora lutea (CL) and unovulated large follicles (UF) in both ovaries were done. Flushings of the oviduct and uterine horn were performed separately using phosphate buffer saline to identify the numbers and locations of embryos.

The duration of estrus(h),numbers of $C L$ and $U F$ were $41.5 \pm$ 11.2, 3.1 \pm 1.3 and $1.1 \pm 0.76$ respectively. The overall ovulation and embryo recovery rates were $\mathbf{7 2 . 5}$ and $\mathbf{5 4 \%}$ respectively.Group without $\mathrm{LH}$ gave low response (50 and $0 \%$ respectively). The higher ovulation rate(66-100\%) were recorded for heifers supplemented with 4000 and more USP unit LH while the higher embryo recovery rates $(50-100 \%)$ were associated with the doses of 4000-7000 unit .

At $72-89 \mathrm{~h}$ postestrus (48-65h post-insemination) 6 embryos were collected from the oviducts and one embryo from the uterus. Some non-motile spermatozoa were observed in the oviduct. At 100106 and 118-120 $\mathrm{h}$ postestrus (76-82 and $94-96 \mathrm{~h}$ post-insemination) 7 and 6 embryos were recovered respectively from the uterus. The rate of embryo transport in the oviduct of superovulated buffalo heifers appeared to be $30 \mathrm{~h}$ and more faster than in buffalo or bovine cows. 


\section{INTRODUCTION}

Field application of recent technology in cattle reproduction still facing a lot of problems in buffaloes. Embryo transfer technique which had been well refined in cattle breeding required more scientific researches to be favourably used in buffalo.

The rate of embryo transport in the oviduct is a matter of vital significance to optimise the day of non surgical collection of embryos from the uterus. In superovulated cows, Hackett et al., (1993) cited that embryos were found in the oviduct upto 6 days from insemination. In superovulated buffalo cows, Drost (1991) reported that embryos reached the uterus arround days 4 to 5 after the onset of estrus. Misra et al., (1998) found that ova/embryos reached the uterus about 134 (h) after the onset of superovulatory estrus in buffalo cows.

The available literature lack similar informations on superovulated buffalo-heifers. Within the scope of this topic, Desaulniers et al., (1995) reported poor response to superovulation in mature cows when compared to heifers less than 2 years old.

Ismail et al., (1993) reported that administration of $\mathrm{LH}$ with FSH improved ovarian response in superovulated buffalo cows. Osman et al. , (2001) found that addition of 2000 unit LH improved significantly the ovulation rate in superovulated buffalo cows in comparison to the control while buffalo heifers showed the lowest level of ovarian response.

Donaldson et al., (1986) cited that excessive LH during treatment to induce superovulation resulted in low rates of fertilization in cow. Thus, optimisation of LH dose might be benefit to get better response.

The aim of the present experiment is to investigate the transport of pre- implantation embryos in the oviduct and uterus of superovulated buffalo heifers. Trials were also performed during the experiment to improve the ovulation and embryo recovery rates using variable doses of $\mathrm{LH}$ injected as an additive to the superovulatory regieme.

\section{MATERIAL AND METHODS}

Twelve buffalo heifers of similar age (21-25 month) and body weight $(325-385 \mathrm{~kg})$ were used for the present experiment. 
These animals were healthy, non pregnant,cycling and selected from a local governamental buffalo farm at El-Hawatka Station, Assiut.

All animals were kept in the farm under the same feeding and management systems. The buffalo heifers were assigned to be at mid luteal phas before starting the superovulatory treatment.

A dose of $1.4 \mathrm{ml}$ Super-Ov contained 12.5 NIH pFSH (Mfd.W.S. Montreal Inc. Canada) was injected i.m. morning and evening for 3 successive days. At the morning of the 3ed day, $5 \mathrm{ml}$ lutalyse contained $25 \mathrm{mg} \mathbf{P G F}_{2 \alpha}$ was injected at the time of the $5^{\text {th }}$ FSH injection.

As a trial to improve ovarian response and embryo recovery rate variable doses of $\mathrm{LH}(0,2,4,5,7$ and 10 thousands USP unit, Steris, Lab, Inc Phoenix, Arizona) were injected at the morning of the $4^{\text {th }}$ day of the treatment in 6 trials each with 2 heifers.

Fertile buffalo bulls were allowed to mount heifers frequently after 24 hours (h) from the onset of estrus.

The superovulated buffaloes were kept untied in open yard. The onset and duration of heat were recorded through close observation by 2 herdsmen in the farm.

Heifers were classified into 3 equal groups ( 2 trials/each) which slaughtered at variable time intervals from the onset of estrus: 72-80, 100-106 and 118-120 (h).

After slaughter, the intact genitalia were dissected free and transported to the lab in a Thermos container at $4 \mathrm{C}^{\circ}$. The number of follicles and corpora lutea in both ovaries were taken. Flushings of the oviduct and uterine horn were performed separately using phosphate buffer saline to identify the numbers and locations of embryos.

Data obtained were expressed as Mean \pm St.Dev. and analyzed statistically using Costat Computer program (1986) .

\section{RESULTS}

The overall duration of estrus (h) was $41.5 \pm 11.2$ while the overall numbers of $C L$ and $U F$ were $3.1 \pm 1.3$ and $1.1 \pm 0.76$ respectively (Table 1). The onset of oestrus began within 24 (h) from the last pFSH in jection. The results of this experiment were distributed according to the time of slaughter in Table 2 . 
At $72-89 \mathrm{~h}$ postestrus (48-65h post-insemination) 6 embryos were collected from the oviducts and one embryo from the uterus. Meaning that $14 \%$ of embryos could reached the uterus at this early period. Some non-motile spermatozoa were observed in the oviduct. The case in which one embryo could be recovered from the uterus at this early period, received 7000 USP unit LH.

After this period all embryos located the uterus. At 100-106 and 118-120 $\mathrm{h}$ postestrus (76-82 and 94-96 $\mathrm{h}$ postinsemination ) 7 and 6 embryos were recovered respectively from the uterus.

Both ovulation and embryo recovery rates were nearly simillar among the different periods of slaughter.

Table 3 showed the results distributed according to the variable doses of $\mathrm{LH}$ additives. The higher ovulation rates (66-100\%) were recorded for heifers supplemented with 4000 and more USP unit LH while the higher embryo recovery rates $(50-100 \%)$ were associated with the doses of 4000-7000 unit .

\section{DISCUSSION}

The recovery of single preimplantion embryo in the uterus of superovulated heifer as early as 72-89 $\mathrm{h}$ postestrus or 48-65 $\mathrm{h}$ post insemination denoted a faster rate of transport by at least 30 (h) and more than those reported in cattle and buffalo by Newcomb et al., (1976) and Misra et al., (1998) respectively. The low embryo recovery rates reported in the present study are in comparable to those reported in superovulated cows and buffaloes by Donaldson (1985) and Baruselli et al., (1994) respectively. The last authors declared that low embryo recoveries in buffalo may be explained by a failure of oocytes to enter the oviduct after superstimulation of follicular growth. Moreover, Osman et al., (2001) focused about the transfer of some unovulated follicles to cysts with consequent reduction in the number of oocytes entering the oviduct.

The overwhelming majority of our data in this experiment suports the conclusion that nonsurgical embryo transfer in buffalo heifers can be carried out successfully as early as the $4^{\text {th }}$ or $5^{\text {th }}$ day from insemination to avoid rapid growth and hatching of the morula. There are conflicting reports regarding the hatching of blastocyst on day 5 (Karaivanov et al., 1987) or day 6 to 7 (Alexiev et al., 1988) in buffalo. In this work all embryos located the uterus at 76-82 (h) post insemination (about 3 to 3.5 day). 
It might be of interest in relation to $L H$ additives, that all heifers received LH gave higher ovarian response than the control group without LH. Moreover, a dose ranged between 4000 and 7000 USP unit LH appeared much appropriate to induce the best ovulation and embryo recovery rates in buffalo heifers. Conflicting results were recorded in cow and buffalo cows with authors used lower doses of LH (1500-3000 IU LH) as cited by Sugie et al., (1980), Ismail et al., (1993) and Osman et al., (2001). The argument developed in this aspect could be traced from the review of Mapletoft and Pierson (1993) who suggest that maximum acceptable level of LH contamination to an FSH preparation is between $15-20 \%$ of the original LH content of the extract. It seems possible that buffalo heifers might need such high dose of $\mathrm{LH}$ in addition to pFSH to express favourable response with superovulation and embryo recovery.

\section{REFERENCES}

Alexiev,A. ; Vlahov,K. ; Karivanov,Ch; Kacheva,D.; Polykhronov,O; Petrov,M.; Nikolov, N. ; Drogoev, A. and Radev, P. (1988): Embryo transfer in buffaloes in Bulgaria. Proc II World buffalo Congress, 11: 591-595.

Baruselli, P. S. ; Madureira, E. H. ; Visintin, J. A. ; Porto-Filho, R. ; Carvalho, N. A. T. ; Campanile, G. and Zicarelli, L. (1994) : Failure of oocyte entry into oviduct in superovulated buffalo . Theriogenology, 41, 330.

Costat Computer Program (1986) : Version 3.03 , Copyright Costat Computer Programm Software.

Desaulniers, D. M. ; Lussier, J.G. ; Goff, A. K. ; Bousquet, D. and Guilbault,L.A. (1995): Follicular development and reproductive endocrinology during and after superovulation in heifers and mature cows displaying contrasting superovulatory responses. Theriogenology , 44, 479.

Donaldson,L.E (1985) : Estimation of superovulation response in donor cows. Vet. Rec. Jul. 13, 117, 2 : 33-4.

Donaldson, L. E. , Word, D. N. and Glenn, S.D. (1986) : Use of porcine follicle stimulating hormone after chromatographe purification in superovulation in cattle. Theriogenology, 25, 747.

Drost,M. (1991): Training Manual for Embryo Transfer in Water buffalo. FAO Animal Production and Health. Paper 84, FAO of the United Nations, Rome. 
Hackett, A. J. ; Durnford, R. ; Mapletoft, R. J. and Marcus, G. J. (1993): Location and status of embryos in the genital tract of superovulated cows 4 to 6 days after insemination. Theriogenology, $40,1147$.

Ismail, S.T. ; Abboud, M. Y. ; Tawfik, M. S. ; Essawi, S. and Mohamed, K. M. (1993) : Effects of HCG and GnRH on the ovulation rate and embryo production in buffalo cows superovulated with PMSG. Buffalo J. 9, 129.

Karaivanov, C. ; Kacheva, D. ; Petrov, M. ; Kacheva, D. ; Stojanova, M. ; Alexiev, A. ; Polihronov, O. and Danev, A. (1987) : Studies on preimplantation development of buffalo embryo. Theriogenology, 28, 747.

Mapletoft, R. J. and Pierson, R. A. (1993) : Factors affecting superovulation in the cow : practical considerations. IETS Embryo Transfer Newsl. , 11, 15.

Misra, A. K. ; Kasiraj, R. ; Mutha R. ,M. ; Rangreddy, N. S. ; Jaiswal, R. S. and Pant, H. C. (1998) : Rate of transport and development preimplantation embryo in the superovulated buffalo (Bubalus bubalis). Theriogenology, 50, 637.

Newcomb, R. ; Rowson,L. E. A. and Trounson, A. O. (1976): The entry of superovulated eggs into the uterus. In Rowson LEA (ed). Egg Transfer in Cattle. Luxembourg: Commission European Communities.

Osman, A. M. ; Shehata, S. H. and Megahed, G. A. (2001) : Superovulatory response and embryo recovery in buffalo heifers and cows treated with FSH (Super-ov) and LH. Vet. Med. , J. Giza. Vol. 49, 3, 483.

Sugie,T. ; Seidel, J. R. and Hafez, E. S. E. (1980) : Embryo Transfer: Reproduction in Farm Animals. Hafez E. S. E. (ed). $4^{\text {th }}$ Ed. Lea and Febiger. Philadelphia : PP. 569. 
Table 1: Durations of estrus (h) and numbers of corpora lutea (CL) and unovulated large follicles (UF) in superovulated buffalo heifers

\begin{tabular}{|c|c|c|c|c|}
\hline $\begin{array}{c}\text { Buffalo } \\
\text { Heifers }\end{array}$ & $\begin{array}{c}\text { Doses of LH } \\
\text { (USP Units) }\end{array}$ & $\begin{array}{c}\text { Durations } \\
\text { of Estrus (h) }\end{array}$ & $\begin{array}{c}\text { Numbers of } \\
\text { CL }\end{array}$ & $\begin{array}{c}\text { Numbers of } \\
\text { UF } \\
(>\mathbf{8} \text { mm })\end{array}$ \\
\hline 1 & $\mathbf{0 0}$ & 46 & 2 & 2 \\
2 & 00 & 46 & 1 & 1 \\
3 & 2000 & 30 & 2 & 2 \\
4 & 2000 & 52 & 2 & 2 \\
5 & 4000 & 36 & 4 & 1 \\
6 & 4000 & 34 & 5 & 0 \\
7 & 5000 & 40 & 5 & 1 \\
8 & 5000 & 33 & 4 & 0 \\
9 & 7000 & 54 & 2 & 1 \\
10 & 7000 & 67 & 4 & 2 \\
11 & 10000 & 30 & 2 & 0 \\
12 & 10000 & 30 & 4 & 1 \\
\hline Mean \pm & & $41.5 \pm 11.2$ & $3.1 \pm 1.3$ & $1.1 \pm \mathbf{0 . 7 6}$ \\
St.Dev. & & & & \\
\hline
\end{tabular}


Table 2 : Results distributed according to the time of slaughter from onset of estrus in superovulated buffalo heifers

\begin{tabular}{|c|c|c|c|c|c|c|}
\hline \multirow{2}{*}{$\begin{array}{l}\text { Time of } \\
\text { slaughter } \\
\text { from } \\
\text { Onset of } \\
\text { Estrus } \\
\text { (hour) }\end{array}$} & \multirow[t]{2}{*}{$\begin{array}{c}\text { Number of } \\
\text { New } \\
\text { CL }\end{array}$} & \multicolumn{2}{|c|}{$\begin{array}{c}\begin{array}{c}\text { Number } \\
\text { of }\end{array} \\
\text { UF }\end{array}$} & \multirow[t]{2}{*}{$\begin{array}{c}\text { Ovulation Rate } \\
\qquad(\%)\end{array}$} & \multicolumn{2}{|c|}{$\begin{array}{c}\text { Number of Recovere } \\
\text { Embryos }\end{array}$} \\
\hline & & $\begin{array}{l}\text { 4-8 } \\
\text { mm }\end{array}$ & $\begin{array}{c}>8 \\
\mathbf{m m}\end{array}$ & & Oviduct & Uterus \\
\hline $\begin{array}{c}72-89 \\
(48-65)\end{array}$ & $\begin{array}{c}3.0 \pm 1.0 \\
(2-4)\end{array}$ & $\begin{array}{c}5.5 \pm 2.8 \\
(3-10)\end{array}$ & $\begin{array}{c}1.0 \pm 0.7 \\
(1-2)\end{array}$ & $\begin{array}{c}78.0 \pm 13.92 \\
(66-100)\end{array}$ & $\begin{array}{c}1.5 \pm 1.1 \\
(1-3)\end{array}$ & $\begin{array}{c}0.5 \pm 0.3 \\
(0-1)\end{array}$ \\
\hline $\begin{array}{l}100-106 \\
(76-82)\end{array}$ & $\begin{array}{c}3.0 \pm 1.58 \\
(1-5)\end{array}$ & $\begin{array}{c}4.0 \pm 1.58 \\
(2-6)\end{array}$ & $\begin{array}{c}1.0 \pm 0.7 \\
(1-2)\end{array}$ & $\begin{array}{c}70.0 \pm 21.21 \\
(50-100)\end{array}$ & - & $\begin{array}{c}1.75 \pm 1.7 \\
(0-4)\end{array}$ \\
\hline $\begin{array}{l}118-120 \\
(94-96)\end{array}$ & $\begin{array}{c}3.25 \pm 1.2 \\
(2-5)\end{array}$ & $\begin{array}{c}4.5 \pm 1.5 \\
(3-6)\end{array}$ & $\begin{array}{c}1.25 \pm 0.82 \\
(0-2)\end{array}$ & $\begin{array}{c}70.8 \pm 21.6 \\
(50-100)\end{array}$ & - & $\begin{array}{c}1.5 \pm 1.11 \\
(0-2)\end{array}$ \\
\hline & $\begin{array}{l}\text { ean } \pm \text { St.D } \\
\text { \& Postins } \\
\text { Range }\end{array}$ & $\begin{array}{r}\mathrm{CL}= \\
\text { aation p }\end{array}$ & $\begin{array}{l}\text { pora lutea } \\
\text { s }\end{array}$ & $\begin{array}{c}\text { UF = Unovulat } \\
\text { n= 4/each gro }\end{array}$ & llicles & \\
\hline
\end{tabular}


Table 3 : Results distributed according to the different dosses of $\mathrm{LH}$ additives in superovulated buffalo heifers

\begin{tabular}{|c|c|c|c|c|c|c|c|c|c|c|c|}
\hline \multirow[t]{3}{*}{$\begin{array}{c}\text { Doses of } \\
\text { LH } \\
\text { (U S P Unit) }\end{array}$} & \multicolumn{2}{|c|}{$\begin{array}{c}\text { Number of } \\
\text { New } \\
\text { CL/animal }\end{array}$} & \multicolumn{4}{|c|}{$\begin{array}{l}\text { Number of } \\
\text { UF/animal }\end{array}$} & \multicolumn{2}{|c|}{$\begin{array}{c}\text { Ovulation } \\
\text { Rate } \\
(\%)\end{array}$} & \multicolumn{2}{|c|}{$\begin{array}{c}\text { Number of } \\
\text { Recovered } \\
\text { Embryos }\end{array}$} & \multirow{3}{*}{$\begin{array}{r}\text { Emb } \\
\text { Reco } \\
\text { Ra } \\
\\
\begin{array}{c}\text { Case } \\
1\end{array} \\
\end{array}$} \\
\hline & & & \multicolumn{2}{|c|}{ 4-8 $\mathrm{mm}$} & \multicolumn{2}{|c|}{$>8 \mathrm{~mm}$} & & & & & \\
\hline & $\begin{array}{c}\text { Case } \\
1 \\
\end{array}$ & $\begin{array}{c}\text { Case } \\
2 \\
\end{array}$ & $\begin{array}{c}\text { Case } \\
1 \\
\end{array}$ & $\begin{array}{c}\text { Case } \\
2 \\
\end{array}$ & $\begin{array}{c}\text { Case } \\
1 \\
\end{array}$ & $\begin{array}{c}\text { Case } \\
2 \\
\end{array}$ & $\begin{array}{c}\text { Case } \\
1 \\
\end{array}$ & $\begin{array}{c}\text { Case } \\
2 \\
\end{array}$ & $\begin{array}{c}\text { Case } \\
1 \\
\end{array}$ & $\begin{array}{c}\text { Case } \\
2 \\
\end{array}$ & \\
\hline 00 & 2 & 1 & 5 & 6 & 2 & 1 & 50 & 50 & 0 & $\mathbf{0}$ & $\mathbf{0}$ \\
\hline 2000 & 2 & 2 & 6 & 6 & 2 & 2 & 50 & 50 & 1 & $\mathbf{0}$ & 50 \\
\hline 4000 & 4 & 5 & 2 & 3 & $\mathbf{1}$ & $\mathbf{0}$ & 80 & 100 & 3 & 4 & 75 \\
\hline 5000 & 5 & 4 & 3 & 3 & 1 & 0 & 83 & 100 & 3 & 2 & 60 \\
\hline 7000 & 2 & 4 & 3 & 3 & 1 & 2 & 66 & 66 & 1 & 4 & 50 \\
\hline 10000 & 2 & 4 & 10 & 6 & $\mathbf{0}$ & 1 & 100 & 80 & $\mathbf{0}$ & 2 & 0 \\
\hline
\end{tabular}
$\mathbf{C L}=$ Corpora lutea
UF = Unovulated follicle 